1 Mercury enrichments in lower Aptian sediments support the link between Ontong Java LIP activity and

\section{OAE 1a}

Guillaume Charbonnier, Karl B. Föllmi

Institute of Earth Sciences, Géopolis, University of Lausanne, CH-1015 Lausanne, Switzerland

\section{Materials and methods: further details}

Three hemipelagic sections situated in different basins were investigated in the western Tethyan Ocean. The Glaise section (SE France, near Gap) is located in the Vocontian Basin, which represents an area of hemipelagic sedimentation characterized by a palaeodepth of a few hundred meters and which is surrounded by three carbonate platforms (Masse, 1993). Discrete dark laminated layers corresponding to the Goguel Level were recognized (Bréhéret, 1997). The temporal framework is well defined by ammonoïd zonation (Bréhéret, 1997). The La Bédoule section (SE France, southeast of Marseille) is considered as the historical stratotype of the Bedoulian (Moullade et al., 1998), and is situated in the South Provencal Basin. The sediments were deposited in an intra-shelf basin, which was separated from the Vocontian Basin by the North Provence Platform (Masse et al., 1999). A marly succession lacking organic-rich layers represents the equivalent to the Goguel Level. The sedimentary succession is well dated by ammonoïds, calcareous nannofossils, and planktonic foraminifera (Moullade et al., 1998). The Roter Sattel section is situated in the "Préalpes Médianes Plastiques" (Préalpes Romandes, Switzerland) and represents the Briançonnais domain - a micro-continent forming a structural high within the former Tethyan Ocean (Stampfli, 1993). The time equivalent of the Selli Level represents an expanded interval including organic-rich layers (Strasser et al., 2001). The temporal biostratigraphic framework is based on the recognition of planktonic foraminiferal assemblages (Strasser et al., 2001).

Precise chemostratigraphic correlations were established using the complex structures of the $\delta^{13} \mathrm{C}_{\text {carb }}$ curves, which are defined as isotope segments C2 to C7 (Menegatti et al., 1998) (Fig. DR1). These $\delta^{13} \mathrm{C}_{\text {carb }}$ records well comparable to those in other parts of the Tethys (Kuhnt et al., 1998; Menegatti et al., 1998; Erba et al., 1999; Stein et al., 2012; Westermann et al., 2013). At the onset of the anoxic event 1a, a negative shift is observed in the $\delta^{13} \mathrm{C}_{\text {carb }}$ records (segment C3). It is followed by a long positive excursion (2\%o) decomposed in three segments: an abrupt step-like positive excursion (segment C4), an subsequent plateau (segment C5), and a second increase (segment C6) to the plateau C7 (Fig. DR1). 


\section{Results and discussion}

The relationship between $\mathrm{Hg}$ contents and TOC enrichments was investigated using the correlation coefficient $R^{2}$ (Fig. DR2). Moderate correlation $\left(R^{2}=0.41\right)$ with the generally moderate TOC $(1-2 \%)$ values is recorded at Roter Sattel during the C2-C3 segments. At Glaise and La Bédoule a correlation is lacking between TOC values and $\mathrm{Hg}$ contents $\left(\mathrm{R}^{2}=0.12\right.$ and 0.16 , respectively).

During the positive carbon isotope excursion (segments C4 to C6), at Roter Sattel and Glaise the overall correlation coefficient is moderately low $\left(\mathrm{R}^{2}=0.48\right.$ and 0.32 respectively; Fig. DR2), indicating that this relationship is not consistently linear. The generally high $\mathrm{Hg}$ values at Roter Sattel and Glaise are partly correlated with the high to moderate TOC values, especially in the lower part of segment C4 and C6, and the higher part of segment C5. During this time interval no correlation exist between these parameters at La Bédoule $\left(R^{2}=0.15\right)($ Fig. DR2).

\section{References cited in the supplementary online material}

Bréhéret, J.G., 1997, L’Aptien et l'Albien de la Fosse vocontienne (des bordures au bassin). Evolution de la sédimentation et enseignements sur les événements anoxiques: Société Géologique du Nord, Mémoire 25, p. 164.

Erba, E., Channell, J.E.T., Claps, M., Jones, C., Larson, R., Opdyke, B., Premoli Silva, I., Riva, A., Salvini, G., and Torricelli, S., 1999, Integrated stratigraphy of the Cismon APTICORE (southern Alps, Italy): a "reference section" for the Barremian-Aptian interval at low latitudes: Journal of Foraminiferal Research, v. 39, p. 371-391.

Kuhnt, W., Moullade, M., Masse, J.P., and Erlen-Keuser, H., 1998, Carbon isotope stratigraphy of the lower Aptian historical stratotype at Cassis-La Bédoule (SE France): Géologie Méditerranéenne, v. 25, p. $63-$ 79.

Kuhnt, W., Holbourn, A., and Moullade, M., 2011, Transient global cooling at the onset of early Aptian oceanic anoxic event (OAE) 1a: Geology v. 39, p. 323-326.

Masse, J.P., 1993, ValanginianeEarly Aptian carbonate platforms from Provence, southeastern France. In: Simo, T., Scott, R.W., Masse, J.-P. (Eds.). Cretaceous Carbonate Platforms. American Association of Petroleum Geologists, Memoir, 56, pp. 363-374.

Masse, J.P., El Albani, and A., Erlenkeuser, H., 1999, Stratigraphie isotopique de l'aptien inférieur de Provence 
(SE France): application aux corrélations plate-forme/ bassin: Eclogae Geologicae Helvetiae, v. 92, p.

\section{Supplementary figures}

82 259-263. p.1-45.

Menegatti, A.P., Weissert, H., Brown, R.S., Tyson, R.V., Farrimond, P., Strasser, A., and Caron, M., 1998, High-resolution $\delta^{13} \mathrm{C}$-stratigraphy through the early Aptian "Livello Selli" of the Alpine Tethys: Paleoceanography, v. 13, p. 530-545.

Moullade, M., Kunht, W., Bergen, J.A., Masse, J.P., and Tronchetti, G., 1998, Correlation of biostratigraphic and stable isotope events in the Aptian historical stratype of La Bédoule (south-east France). C. R. Académie des Sciences Paris v. 327, p. 693-698.

Stampfli, G.M. 1993, Le Briançonnais, terrain exotique dans les Alpes? Eclogae geologicae Helvetiae, v. 86,

Stein, M., Westermann, S., Adatte, T., Matera, V., Fleitmann, D., Spangenberg, J.E., and Föllmi, K.B., 2012 , Late Barremian-Early Aptian palaeoenvironmental change: The Cassis-La-Bédoule section, southeast France: Cretaceous Research v. 37, p. 209-222.

Strasser, A., Caron, M., and Gjermeni, M., 2001, The Aptian, Albian and Cenomanian of Roter Sattel, Romandes Prealps, Switzerland: A high-resolution record of oceanographic changes: Cretaceous Research, v. 22, p. 173-199.

Westermann, S., Stein, M., Matera, V., Fiet, N., Fleitmann, D., Adatte, T., and Föllmi, K.B., 2013, Rapid changes in the redox conditions of the western Tethys Ocean during the early Aptian oceanic anoxic event: Geochimica et Cosmochimica Acta, v. 121, p. 467-486.

Fig. DR1: Correlation of the stratigraphic $\delta^{13} \mathrm{C}$ records from Roter Sattel (Menegatti et al., 1998), La Bédoule (Kuhnt et al., 1998, 2011), and Glaise (Westermann et al., 2013).

Fig. DR2: $\mathrm{Hg}(\mathrm{ppb})$ versus TOC (\%) diagram for segments C2-C3 and C4-C6. 
Roter Sattel (Briançonnais Domain)

Segment C2-C3

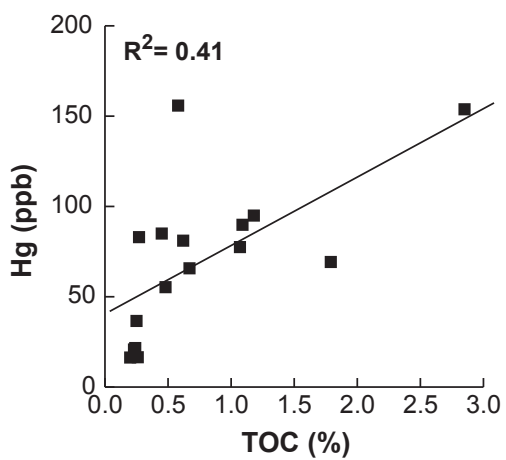

Segment C4-C6: Positive excursion

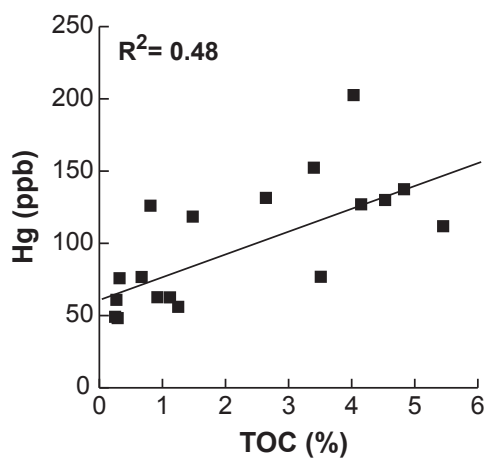

Glaise (Vocontian Basin)

Segment C2-C3

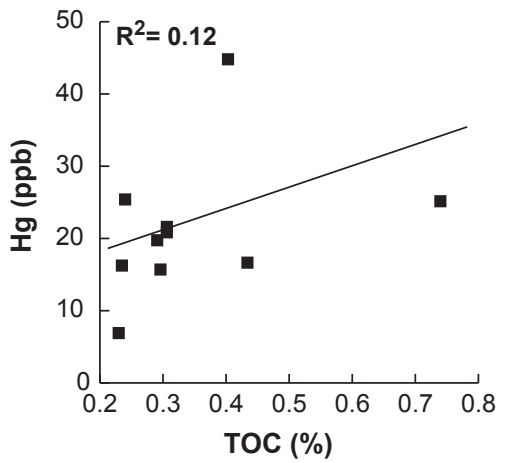

Segment C4-C6: Positive excursion

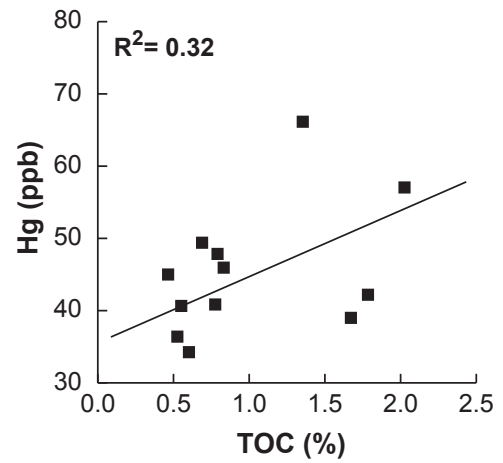

\section{La Bédoule (South Provencal Basin)}

\section{Segment C2-C3}

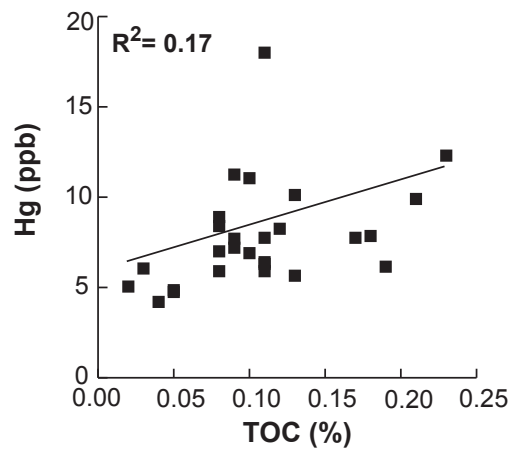

Segment C4-C6: Positive excursion

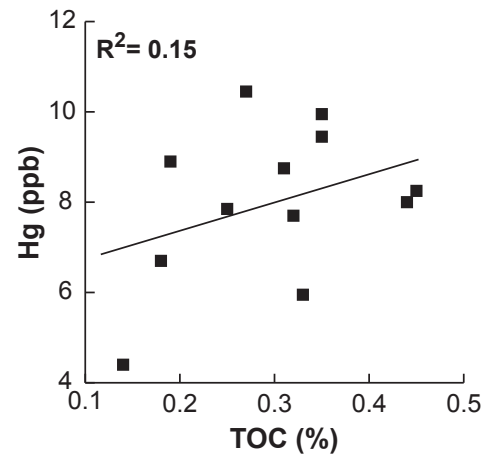

Figure DR2 